\title{
DESAIN SISTEM INFORMASI PENJUALAN MENGGUNAKAN PHP PADA CV. BERKAT BERSAMA DENGAN METODOLOGI BERORIENTASI OBJEK
}

\author{
Hamidah \\ Program Studi Sistem Informasi, STMIK Atma Luhur Pangkalpinang \\ Jl. Jend Sudirman Baru Kec. Pangkalbalam, Pangkalpinang \\ Telp : (0717) 433506 Fax : (0717) 433506 \\ Email : hamidah.atma@gmail.com
}

\begin{abstract}
Abstrak
Dalam dunia bisnis kebutuhan akan teknologi informasi pada masa sekarang ini merupakan kebutuhan yang sangat penting. Hal ini dikarenakan sudah banyak jalan bisnis dikendalikan menggunakan teknologi informasi dan tidak lepas dari teknologi informasi dalam pengembangan usahanya. Untuk itu, informasi berperan penting dalam kehidupan masyarakat khususnya bagi masyarakat yang menekuni dunia bisnis. Adapun penelitian kali ini akan mengangkat tema penjualan pada CV. Berkat Bersama. Adapun penelitian ini berawal dari karena adanya permasalahan pada $C V$. Berkat Bersama yang terkadang kesulitan dalam pengontrolan data penjualan, ketersediaan stok barang dan sistem yang masih dilakukan secara manual. Untuk itu, penulis berusaha memberikan solusi bagi pimpinan CV. Berkat Bersama dengan cara membuatkan sistem yang terkomputerisasi menggunakan Bahasa Pemrograman PHP agar proses penjualan ini berjalan lancar dan tentunya dapat menguntungkan bagi pemilik perusahaan.
\end{abstract}

Kata kunci : Sistem Informasi, Penjualan, PHP

\section{PENDAHULUAN}

\subsection{Latar Belakang Permasalahan}

Dengan berkembangnya ilmu pengetahuan dan teknologi saat ini, informasi sangat berperan penting pada semua aspek kehidupan terutama bagi mereka yang menekuni dunia bisnis. Dengan tidak adanya pengelolaan arus informasi dapat mengakibatkan kekacauan dalam pengambilan keputusan dan pengendalian operasional perusahaan. Dengan adanya kemajuan teknologi khususnya komputer, dapat mencermati peluang yang ada saat ini karena komputer merupakan sarana penunjang utama bagi sistem informasi saat ini. Tidak bisa dipungkiri bahwa komputer sebagai sarana pengolahan data yang cepat sehingga dapat menghasilkan informasi yang dibutuhkan dengan cepat pula.

Adapun permasalahan pada CV. Berkat Bersama adalah pengontrolan data yang todak terkendali, pencarian data yang lambat dan masih menggunakan sistem manual. Untuk itu, penulis akan memberikan solusi kepada pimpinan $\mathrm{CV}$. Berkat Bersama untuk menyediakan program aplikasi yang terkomputerisasi agar pengontrolan data lebih terkendali dan pencarian data lebih cepat dan akurat.

\subsection{Ruang Lingkup Penelitian}

Dalam penelitian ini hanya menitikberat pada proses penjualan barang saja, maka penulis hanya membahas masalah-masalah yang menyangkut analisa pada kegiatan penjualan antara lain :

a. Pendataan Barang

b. Pendataan Pelanggan atau Customer

c. Pemesanan Barang oleh Pelanggan

d. Pemcetakan Nota Pelanggan

e. Pencetakan Laporan Kepada Pimpinan

\subsection{Tujuan Penelitian}

Tujuan dari penelitian ini adalah :

a. Membuat rancangan aplikasi sistem informasi penjualan dengan PHP

b. Membuat Database sebagai tempat penyimapan data

\subsection{Manfaat Penelitian}

Manfaat dari penelitian ini adalah untuk mendukung Kegiatan CV. Berkat Bersama dengan cara menyediakan program aplikasi yang akan digunakan yang dapat melakukan pengolahan data lebih cepat dan juga dapat mempermudah dalam penyimpanan data sehingga mudah menyajikan informasi yang diperlukan oleh semua bagian. 


\section{TINJAUAN PUSTAKA}

\subsection{Konsep Sistem Informasi}

a. Pengertian Sistem

Pengertian Sistem adalah suatu jaringan kerja dari prosedur-prosedur yang saling berhubungan, berkumpul bersama untuk melakukan suatu kegiatan atau untuk menyelesaikan suatu sasaran tertentu ${ }^{[6]}$. Selain itu, Sistem adalah sekelompok unsur yang erat berhubungan satu dengan lainnya, yang berfungsi bersama-sama untuk mencapai tujuan tertentu ${ }^{[9]}$.

Sistem juga adalah kumpulan dari komponen-komponen peralatan model requirements, function dan interface. Sistem adalah sekelompok elemen yang terintegrasi dengan maksud yang sama untuk mencapai suatu tujuan ${ }^{[8]}$.

Dari defenisi ini dapat dirinci lebih lanjut pengertian sistem secara umum, yaitu :

1) Setiap sistem terdiri dari unsur-unsur

2) Unsur-unsur tersebut merupakan bagian terpadu sistem yang bersangkutan.

3) Unsur sistem tersebut bekerja sama untuk mencapai tujuan sistem.

4) Suatu sistem merupakan bagian dari sistem lain yang lebih besar

\section{b. Pengertian Informasi}

Informasi adalah data yang sudah diproses atau diorganisasi ulang menjadi bentuk yang berarti ${ }^{[5]}$.

Informasi merupakan hasil pengolahan data sehingga menjadi bentuk yang penting bagi penerimanya dan mempunyai kegunaan sebagai dasar dalam pengambilan keputusan yang dapat dirasakan akibatnya secara langsung pada saat mendatang [13].

Informasi adalah data yang sudah diolah menjadi suatu bentuk yang berarti bagi penerimanya dan bermanfaat dalam mengambil keputusan saat ini atau mendatang [6].

Informasi adalah salah satu jenis sumber daya yang tersedia bagi manajer, yang dapat dikelola seperti halnya sumber daya yang lain. Informasi dari komputer dapat digunakan oleh para manajer, non manajer, serta orang-orang dan organisasi-organisasi dalam lingkungan perusahaan ${ }^{[7]}$.

\section{c. Pengertian Sistem Informasi \\ Menurut Abdul Kadir menyebutkan} definisi sistem informasi menurut Turban, Mcrean, dan Wetherbe (1999) yaitu: "sistem informasi adalah mengumpulkan, memproses, menyimpan, menganalisis, dan menyebarkan informasi untuk tujuan yang spesifik" [5].

Sistem Informasi adalah suatu system dalam suatu organisasi yang mempertemukan kebutuhan pengolahan transaksi harian, mendukung orerasi, bersifat manajerial, dan kegiatan strategi dari suatu organisasi dan menyediakan pihak luar tertentu dengan laporan-laporan yang dibutuhkan ${ }^{[8]}$

Sistem Informasi adalah seperangkat komponen yang saling berhubungan yang berfungsi mengumpulkan, memproses, menyimpan dan mendistribusikan informasi untuk mendukung pembuatan keputusan dan pengawasan dalam organisasi [3].

Sistem informasi terdiri dari komponen-komponen yang disebut blok bangunan (building blok), yang terdiri dari komponen input, komponen model, komponen output, komponen teknologi, komponen hardware, komponen software, komponen basis data, dan komponen kontrol. Semua komponen tersebut saling berinteraksi satu dengan yang lain membentuk suatu kesatuan untuk mencapai sasaran.

a. Komponen input

Input mewakili data yang masuk kedalam sistem informasi. Input disini termasuk metode dan media untuk menangkap data yang akan dimasukkan, yang dapat berupa dokumendokumen dasar.

b. Komponen model

Komponen ini terdiri dari kombinasi prosedur, logika, dan model matematik yang akan

memanipulasi data input dan data yang tersimpan di basis data dengan cara yag sudah ditentukan untuk menghasilkan keluaran yang diinginkan.

c. Komponen output

Hasil dari sistem informasi adalah keluaran yang merupakan informasiyang berkua litas dan dokumentasi yang berguna untuk semua pemakai sistem.

d. Komponen teknologi

Teknologi merupakan "tool box" dalam sistem informasi, Teknologi digunakan untuk menerima input, menjalankan model, menyimpan dan mengakses data, neghasilkan dan mengirimkan keluaran, dan membantu pengendalian dari sistem secara keseluruhan.

e. Komponen hardware

Hardware berperan penting sebagai suatu media penyimpanan vital bagi sistem informasi. Yang berfungsi sebagai tempat untuk menampung database atau lebih mudah dikatakan sebagai sumber data dan informasi untuk memperlancar dan mempermudah kerja dari sistem informasi.

f. Komponen software

Software berfungsi sebagai tempat untuk mengolah,menghitung dan memanipulasi data 
yang diambil dari hardware untuk menciptakan suatu informasi.

g. Komponen basis data

Basis data (database) merupakan kumpulan data yang saling berkaitan dan berhubungan satu dengan yang lain, tersimpan di pernagkat keras komputer dan menggunakan perangkat lunak untuk memanipulasinya. Data perlu disimpan dalam basis data untuk keperluan penyediaan informasi lebih lanjut. Data di dalam basis data perlu diorganisasikan sedemikianrupa supaya informa si yang dihasilkan berkualitas. Organisasi basis data yang baik juga berguna untuk efisiensi kapasitas penyimpanannya. Basis data diakses atau dimanipulasi menggunakan perangkat lunak paket yang disebut DBMS (Database Management System).

h. Komponen kontrol

Banyak hal yang dapat merusak sistem informasi, seperti bencana alam, api, te,peratur, air, debu, kecurangan-kecurangan, kegagalan-kegagalan sistem itu sendiri, ketidak efisienan, sabotase dan lain sebagainya. Beberapa pengendalian perlu dirancang dan diterapkan untuk meyakinkan bahwa hal-hal yang dapat merusak sistem dapat dicegah ataupun bila terlanjur terjadi kesalahan-kesalahan dapat langsung cepat diatasi.

\subsection{Analisa Sistem Berorientasi Objek}

Analisa sistem adalah suatu proses untuk mengidentifikasikan dan mengevaluasi permasalahan - permasalahan, penyebab penyebab masalah, mengeditifikasikan kebutuhan - kebutuhan sistem, dan memahami secara keseluruhan tentang sistem yang akan kita kembangkan. Tujuan utama dari analisa berorientasi objek adalah memodelkan sistem yang nyata dengan menekan apa yang harus dilakukan sistem.

a. Activity Diagram

Menurut Munawar (2005:109) Activity diagram adalah teknik untuk mendeskripsikan logika procedural, proses bisnis dan aliran kerja dalam banyak kasus. Activity diagram mempunyai peran seperti halnya flowchart, akan tetapi perbedaannya dengan flowchart adalah Activity Diagram bisa mendukung perilaku pararel sedangkan flowchart tidak bisa [10].

\section{b. Use Case Diagram}

Menurut Munawar ( $2005: 63$ ) Use case diagram menggambarkan kebutuhan sistem dari sudut pandang user dan memfokuskanpada proses komputerisasi. Sebuah use case dapat mmenggambarkan hubungan antara use case dengan actor. Secara umum use case adalah pola perilaku sistem dan urutan transaksi yang berhubungan yang dilakukan oleh satu actor ${ }^{[10]}$.

\subsection{Perancangan sistem Berorientasi Objek}

Perancangan sistem berorientasi objek merupakan proses spesifikasi yang terperinci atau pendefinisian dari kebutuhan-kebutuhan fungsional dan persiapan untuk rancang bangun implementasi yang menggambarkan bagaimana suatu sistem baru dilakukan dengan menguraikan hubungan proses-proses dalam bentuk diagram-diagram.

Diagram - diagram UML yang digunakan penulis dalam merancang sistem berorientasi objek adalah :

\section{a. ERD}

ERD menggambarkan hubungan antar data yang ada dan tidak menggambarkan prosesprose yang terjadi. ERD merupakan suatu model untuk menjelaskan hubungan antar data dalam basis data berdasarkan objek - objek dasar data yang mempunyai hubungan antar relasi.

b. Rancangan Layar

Rancangan tampilan layar adalah bentuk tampilan sistem dilayar computer sebagai sarana antar muka/pemakai yang akan dihasilkan dari sistem yang dirancang.

\subsection{Sistem Informasi Penjualan}

Kegiatan penjualan merupakan suatu usaha yang dilakukan untuk mendistribusikan barang kebutuhan yang telah dihasilkan oleh produsen kepada konsumen yang memerlukan dengan memperoleh jasa berupa uang menurut harga.

\subsection{Internet}

Internet adalah metode untuk menghubungkan berbagai komputer ke dalam satu jaringan komputer global, melalui protokok yang disebut Transmission Control Protocol/ Internet Protokol (TCP/ IP). Protokol adalah suatu petunjuk yang menunjukkan pekerjaan yang akan pengguna lakukan dengan internet, apakah akan mengakses situs web melakukan transfer file, mengirim email, dan sebagainya [1].

Internet sendiri berasal dari kata interconnection-networking, merupakan sistem global dari seluruh jaringan komputer yang saling terhubung menggunakan standar Internet Protocol Suite (TCP/IP) untuk melayani miliaran pengguna di seluruh dunia. Manakala Internet (huruf 'I' besar) ialah sistem komputer umum, yang berhubung secara global dan menggunakan TCP/IP sebagai protokol pertukaran paket (packet switching communication protocol). Rangkaian internet yang terbesar dinamakan Internet. Cara menghubungkan rangkaian dengan kaedah ini dinamakan internetworking. 


\subsection{Web server}

Web server adalah perangkat lunak server yang berfungsi menerima permintaan HTTP atau HTTS dari client yang dikenal dengan nama web browser dan akan mengirim kembali hasilnya dalam bentuk halaman-halaman web yang umumnya berbentuk dokumen HTML [1]. Salah satu web server yang banyak dipakai adalah Aphace. Aphace merupakan web server antara flatform yang dapat berjalan dibeberapa platform seperti Linux dan Windows.

\subsection{Sejarah PHP}

PHP adalah script yang berjalan pada server side yang ditambahkan pada HTML. Script ini akan membuat suatu aplikasi yang dapat diintegrasikan kedalam HTML sehingga suatu halaman HTML tidak lagi bersifat statis, namun menjadi bersifat dinamis. Sifat server side membuat pengerjaan script tersebut dikerjakan di server sedangkan yang dikirimkan kepada browser adalah hasil proses dari script tersebut yang sudah berbentuk HTML ${ }^{[1]}$.

PHP dibuat pada tahun 1994 oleh Rasmus Lerdof. Tetapi dikembangkan oleh orang lain dan setelah memulai tiga kali karya penulisan, akhirnya PHP menjadi bahasa pemrograman web. PHP adalah sebuah produk yang berbentuk open source, sehingga source code-code dari PHP dapat digunakan, diganti, diedit tanpa harus dikenakan biaya.

\subsection{Kelebihan dan kelemahan PHP} adalah:

Kelebihan PHP sebagai bahasa server side

a. Bahasa pemrograman PHP adalah sebuah bahasa script yang tidak melakukan sebuah kompilasi dalam penggunaannya.

b. Web server yang mendukung PHP dapat ditemukan dimana-mana dari mulai IIS sampai dengan Aphace, dengan konfigurasi yang relative mudah.

c. Dapat digunakan diberbagai mesin (Linux, Unix, Windows) dan dapat dijalankan secara runtime melalui console serta juga dapat menjalankan perintah-perintah sistem.

\section{Adapun kelemahan PHP adalah:}

a. Tidak ideal untuk pengembangan skala besar.

b. Tidak bisa memisahkan antara tampilan dengan logic dengan baik ( walaupun pengguna template dapat memperbaikinya)

c. PHP memiliki kelemahan security tertentu apabila programmer tidak jeli dalam melakukan pemrograman dan kurang memperhatikan isu dan konfigurasi PHP.

\subsection{Database}

Database atau sering disebut basis data adalah sekumpulan informasi yang disimpan dalam komputer secara sistematik dan merupakan sumber informasi yang dapat diperiksa menggunakan sesuatu program komputer [12]. Database berfungsi untuk menyimpan informasi atau data. Untuk mengelola database diperlukan software yang sering disebut dengan DBMS ( Database Manajemen System ). Dengan DBMS pengguna atau user dapat membuat, mengelola dan mengontrol dan mengakses database dengan mudah, praktis dan efisien.

\subsection{MySql}

MySQL adalah sebuah aplikasi Relational Database Managemen Server (RDBMS) [ 12]. Dengan menggunakan MySQL server, maka data dapat diakses oleh banyak pemakai secara bersamaan. MySQL menggunakan bahasa SQL (Structure Query Language) yaitu bahasa pemrograman standar yang digunakan untuk mengakses server database.

Tiap database memiliki table-tabel, tiap tabel memiliki field-field. Umumnya informasi tersimpan dalam tabel-tabel yang secara logis merupakan struktur-struktur dimensi terdiri atas baris dan kolom. Field-field tersebut dapat berupa data seperti int, real, char, date, time, dan lainnya.

\subsection{Keunggulan MySql}

a. Bekerja pada berbagai platform (tersedia berbagai versi untuk berbagai sistem operasi).

b. Pengaksesan database dapat dilakukan dengan mudah.

c. Memiliki jenis kolom yang cukup banyak sehingga memudahkan konfigurasi sistem database.

d. Mendukung record yang memiliki kolom dengan panjang tetap atau panjang bervariasi.

e. MySQL dan PHP saling terintegrasi, maksudnya adalah pembuatan database dengan menggunakan sintak PHP dapat dibuat. Sedangkan input yang dimasukkan melalui aplikasi web yang menggunakan script server side seperti PHP dapat langsung dimasukkan ke database MySQL yang ada di server dan tentunya web tersebut berada di sebuah web server.

\subsection{Macromedia Dreamweaver 8}

Macromedia Dreamweaver adalah sebuah editor HTML professional untuk mendesain secara visual dan mengelola situs web maupun halaman web [1]. Saat ini 
Dreamweaver merupakan software utama yang digunakan oleh web desainer maupun web programmer dalam membangun suatu situs web. Dreamweaver memberikan kemudahan bagi penggunanya dalam menentukan ruang kerja yang diinginkan. Tipe ruang kerja ditentukan berdasarkan kebutuhan maupun kebiasaan pemakainya. Ruang kerja, fasilitas, dan kemampuan Dremweaver mampu meningkatkan produktivitas dan efektifitas dalam desain maupun dalam membangun sebuah situs web. Macromedia Dreamweaver 8 telah mengalami banyak perbaikan dan peningkatan dari versi sebelumnya, yang mana user interface yang lebih baik dari versi 4, karena adanya peningkatan kemampuan toolbar sehingga dapat memakai toolbar yang sudah ada atau menambahkan fungsi baru.

\subsection{XАMPP}

XAMPP merupakan salah satu paket installasi Apache, PHP dan MySQL instant yang dapat kita gunakan untuk membantu proses installasi ketiga produk tersebut ${ }^{[1]}$. Selain paket installasi instant, XAMPP versi 1.6.4 juga memberikan fasiltias pilihan pengunaan PHP4 atau PHP5. Untuk berpindah versi PHP yang ingin digunakan juga sangat mudah dilakukan dengan mengunakan bantuan PHP-Switch yang telah disertakan oleh XAMPP, dan yang terpenting XAMPP bersifat free atau gratis untuk digunakan. Xampp telah mengalami perkembangan dari waktu ke waktu. Versi terbaru adalah revisi edisi sebelumnya.

Aplikasi utama dalam paket xampp setidaknya terdiri atas web server apache, mysql, PHP dan phpmyadmin.

\subsection{Apache}

Apache adalah web server open source, jika semua orang dipersilahkan memakainya dengan gratis bahkan bisa mengedit kode programnya [1]. Fungsi utama apache menghasilkan halaman web yang benar sesuai dengan yang telah dibuat oleh seorang programmer dengan menggunakan kode PHP.

\section{METODE PENELITIAN}

Metode penelitian adalah menggambarkan cara mengumpulkan informasi-informasi atau data-data yang diperlukan sebagai bahan untuk pembuatan penelitian ini. Adapun metode penelitian ini adalah sebagai berikut :

\subsection{Metode Pengumpulan Data}

Metode pengumpulan data yaitu mendapatkan data dengan cara :

a. Observasi

Kegiatan ini dilakukan untuk mengumpulkan data dengan cara pengamatan langsung dengan hal-hal yang berkaitan dengan pembelian yang sekaligus bahan masukan untuk penulisan skripsi ini.

b. Wawancara

Mempelajari dan menganalisa sistem yang sedang berjalan serta mendapatkan data langsung dari sumbernya dengan tanya jawab, dan wawancara diharapkan informasi yang diperoleh benar-benar dapat dipertanggung jawabkan atas pernyataan yang diajukan.

c. Studi Kepustakaan

Metode ini dimaksudkan untuk memperoleh informasi yang ada hubungannya dengan masalah penelitian yaitu informasi yang bersumber pada buku-buku, bahan kuliah dan bacaan lainnya.

\section{HASIL DAN PEMBAHASAN}

\subsection{Proses Bisnis}

Prosedur yang dilakukan pada CV. Berkat bersama dalam sistem penjualan yang berjalan adalah sebagai berikut :

1) Catat Daftar Harga Barang

Pimpinan memberikan rincian harga-harga yaitu berupa daftar harga barang. Bagian penjualan mencatat daftar harga barang tersebut dan data tersebut dijadikan arsip.

2) Proses Transaksi Penjualan

Pelanggan memesan barang datang langsung maupun lewat telepon kemudian bagian penjualan akan menerima pesanan barang, setelah itu bagian penjualan memeriksa persedian barang. Jika persediaan barang ada, maka bagian penjualan mencatat pesanan barang dan membuatkan nota untuk pelanggan. Kemudian pelanggan melakukan pembayaran berdasarkan nota kepada bagian penjualan. Jika persediaan barang tidak ada, maka pesanan barang dibatalkan.

\section{3) Proses Pembuatan Laporan}

Sebagai bukti pertanggung jawaban kepada pimpinan, maka Pada akhir bulan bagian penjualan membuat laporan penjualan yang akan diserahkan kepada pimpinan untuk mengetahui hasil daripada proses penjualan guna kelangsungan perusahaan.

\subsection{Activity Diagram}

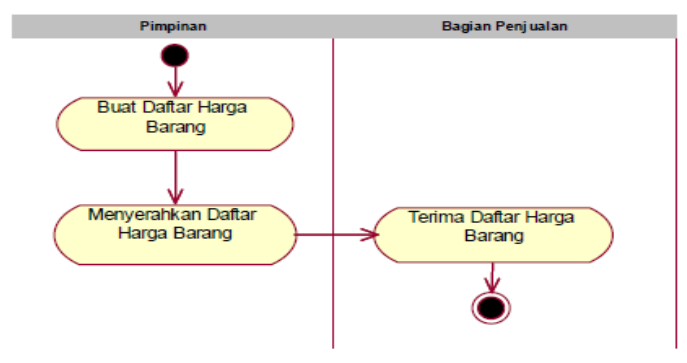

Gambar 4.1 Activity Diagram Daftar Harga Barang 


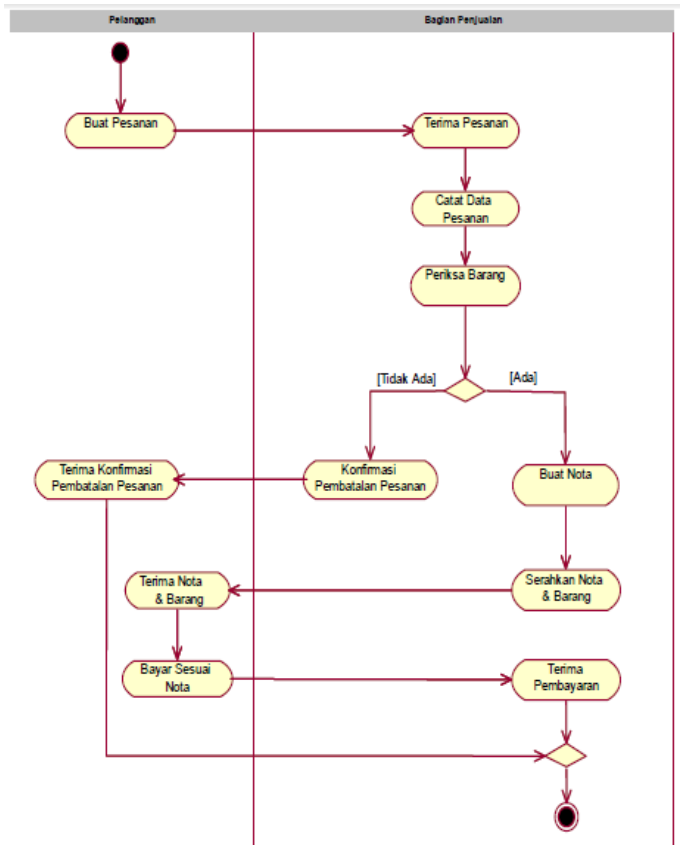

Gambar 4.2 Activity Diagram Transaksi Penjualan

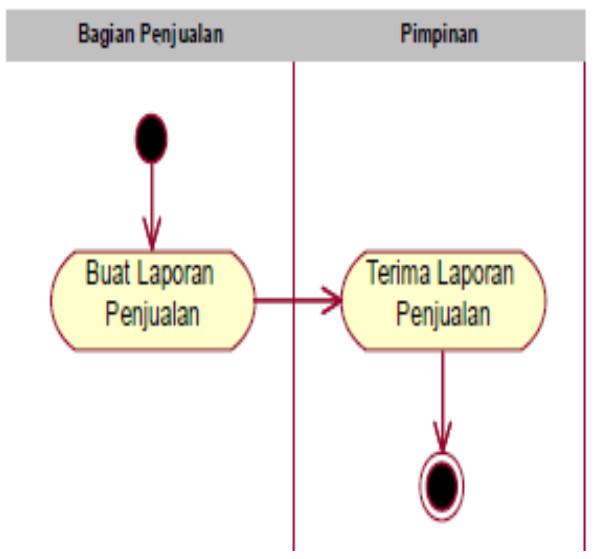

Gambar 4.3 Activity Diagram Laporan

\subsection{Sistem Usulan}

\section{a. Use Case Diagram}

Use case diagram menggambarkan fungsional yang diharapkan dari sebuah sistem yang ditenkan adalah " apa " yang diperbuat sistem dan bukan bagaimana. Use case juga menggambarkan kebutuhan sistem dari sudut pandang user. Use case diagram terdiri dari actor, use case dan relationship.

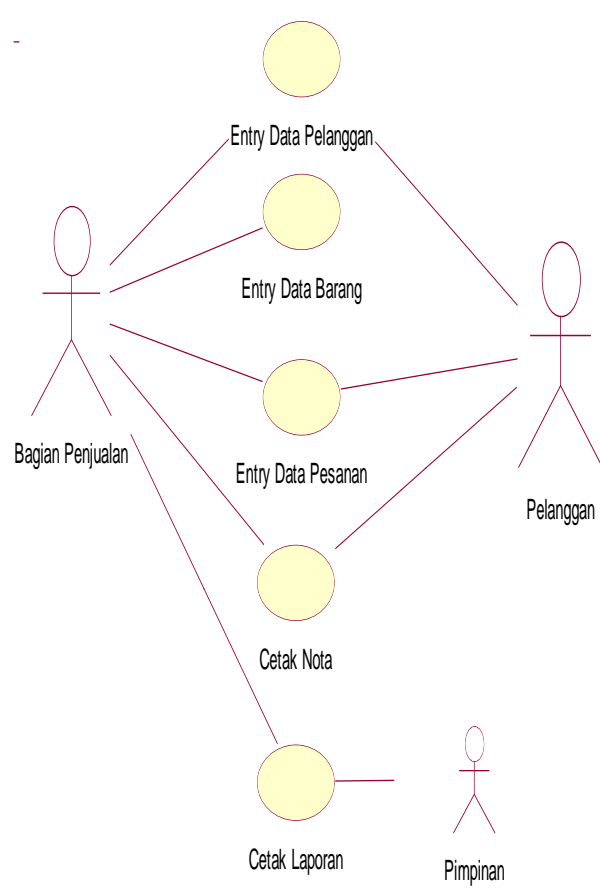

Gambar 4.4 Use Case Diagram

\section{b. Rancangan Basis Data}

Proses menciptakan perancangan untuk basis data yang akan mendukung operasi dan tujuan perusahaan. Dalam merancang suatu basis data atau database digunakan metodologi metodologi yang membantu dalam tahap perancangan basis data. Metodologi perancangan basis data adalah pendekatan struktur dengan menggunakan prosedur, teknik, alat serta bantuan dokumen untuk membantu dan memudahkan dalam proses perancangan.

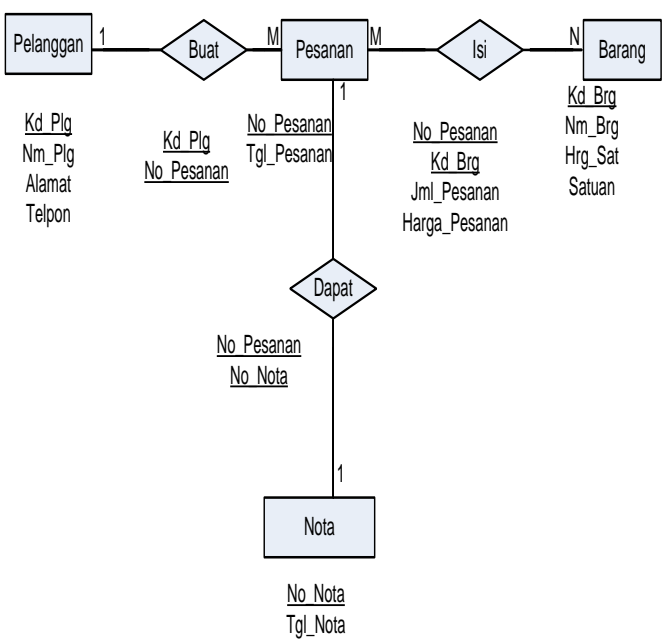

Gambar 4.5 Entity Relationship Diagram 


\section{c. Rancangan Layar}

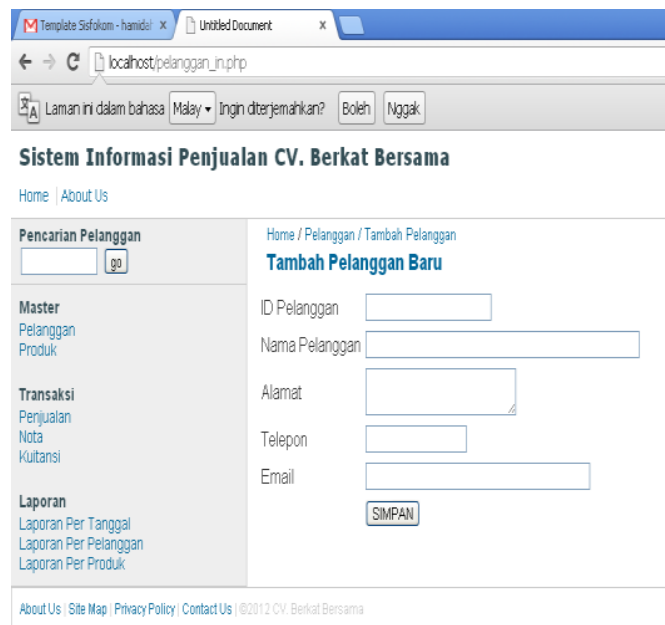

Gambar 4.6 Rancangan Layar Entry Pelanggan

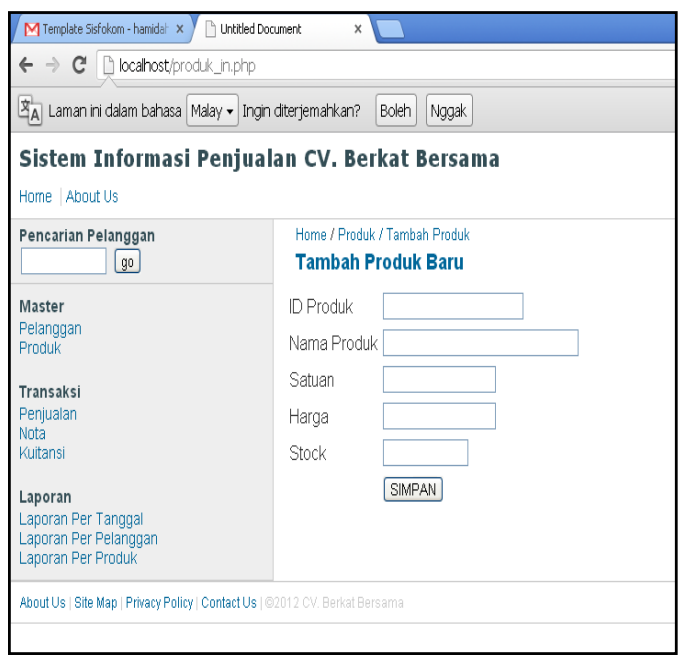

Gambar 4.7 Rancangan Layar Entry Barang

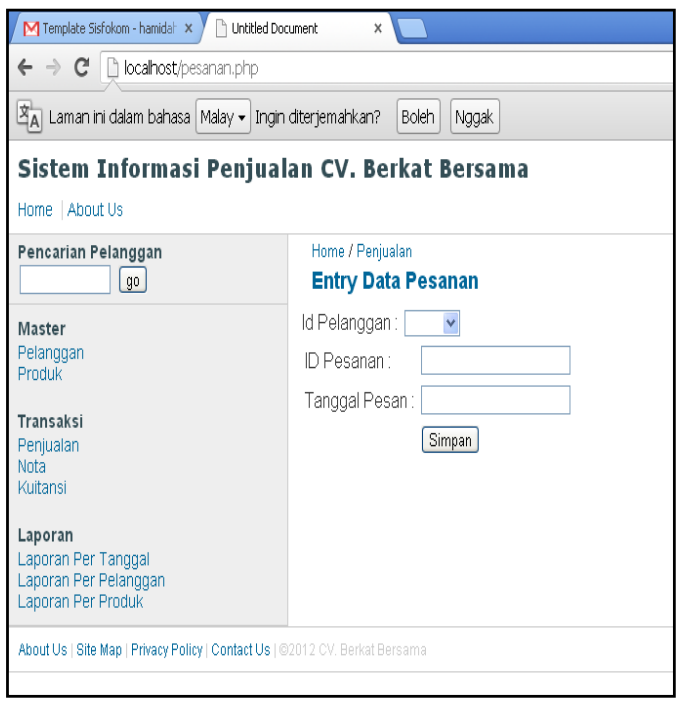

Gambar 4.8 Rancangan Layar Entry Pesanan

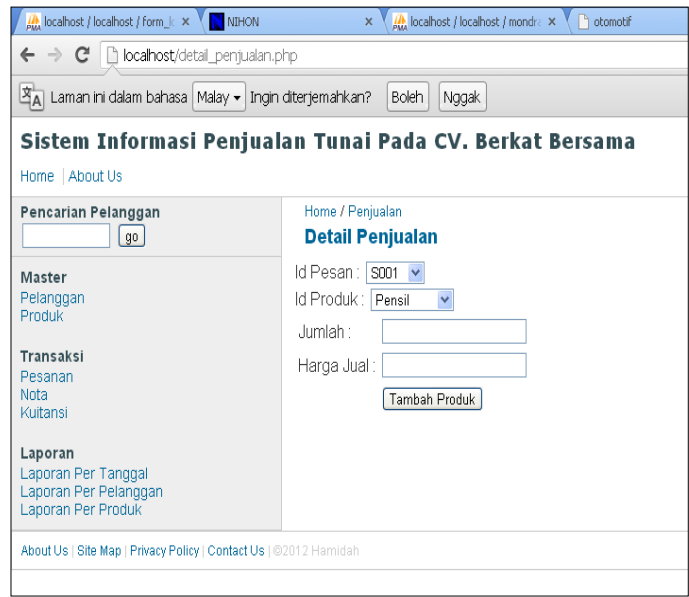

Gambar 4.9 Rancangan Layar Detail Pesanan

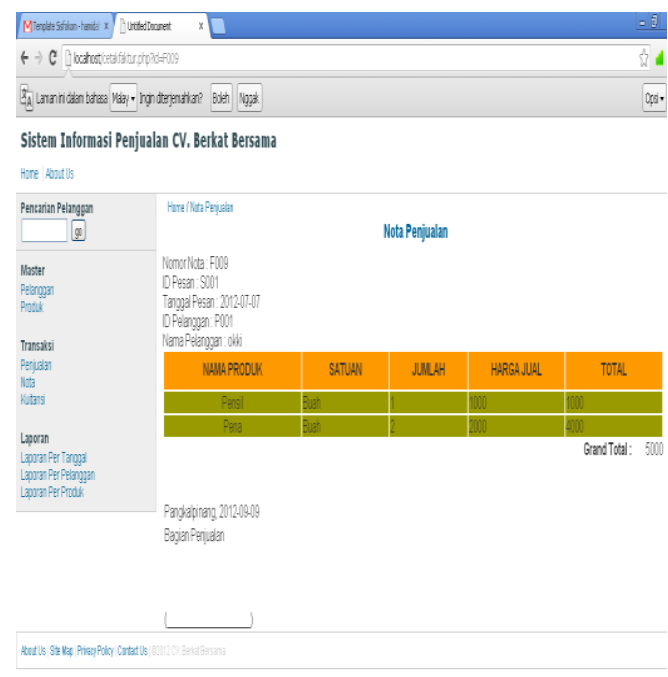

Gambar 4.10 Rancangan Layar Cetak Nota

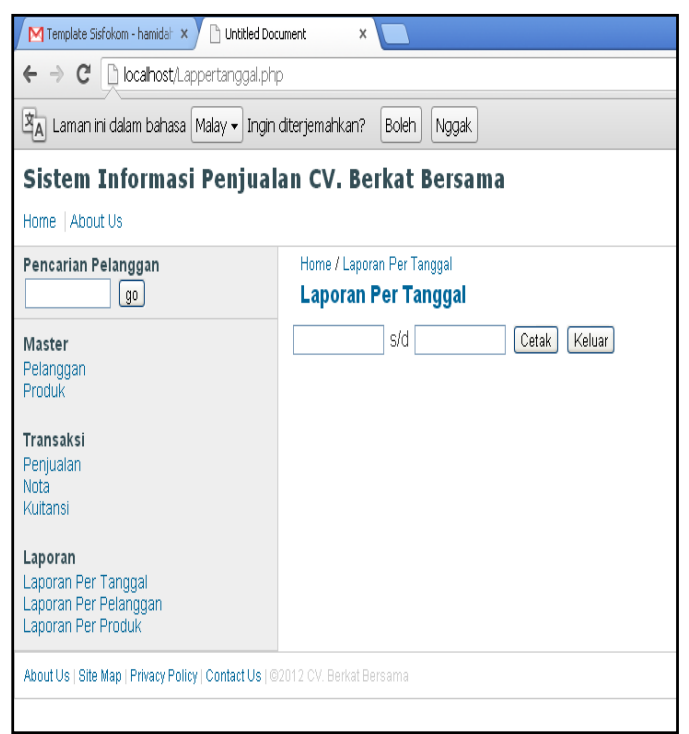

Gambar 4.11 Rancangan Layar Cetak Laporan Penjualan 


\section{KESIMPULAN}

Setelah penulis melakukan penelitian pada CV. Berkat Bersama dan melakukan perbandingan antara sistem yang berjalan dengan sistem yang dirancang atau yang akan diusulkan, maka penulis dapat menarik kesimpulan bahwa :

a. Dengan adanya sistem penjualan yang terkomputerisasi, maka pengolahan data, penyajian informasi akan lebih cepat serta keamanan data akan terjamin karena tempat atau media penyimpanan lebih terjaga dibandingkan dengan pengolahan data secara manual.

b. Sistem komputerisasi diharapkan dapat mengurangi kesalahan pencatatan dan perhitungan jumlah barang atau Human Error.

c. Dengan sistem yang terkomputerisasi dapat mengetahui persedian barang yang telah habis atau barang yang laku terjual.

d. Dengan adanya sistem yang terkomputerisasi, maka laporan yang dihasilkan lebih cepat dan lebih akurat sehingga memudahkan dalam pengambilan keputusan oleh pimpinan perusahaan tersebut.

\section{DAFTAR PUSTAKA}

[1] Aditya, Alan Nur. (2011). Jago PHP dan Mysql. Dunia Komputer, Bandung.

[2] Fathansyah, Basis Data (2007). Basis Data. Informatika. Bandung.

[3] Husein, Muhammad Fakhri, Sistem Informasi Manajemen edisi Revisi, Yogyakarta: Unit Penerbit \& Percetakan AMP YKPN, 2002.

[4] Jogiyanto, HM. (2005). Analisis dan Desain Sistem Informasi, Andi Offset, Yogyakarta.

[5] Kadir , Abdul. (2003). Pengenalan Sistem Informasi. Andi Offset, Yogyakarta.

[6] Mathiassen, Lars, dkk. (2000) Object Oriented Analysis and Design. Marko Publishing. APS,. Denmark.

[7] Mcleod, Raymond. Management Information System. Seventh Edition. Prentice Hall, New Jersey, 1998.

[8] Mcleod, Raymond. Sistem Informasi Manajemen. Edisi ke-tujuh : jilid 1. PT. Prenhallindo, 2001. Jakarta.

[9] Mulyadi. (2001). Sistem Akuntansi. Edisi ke-tiga. Salemba 4, Jakarta.

[10] Munawar. (2005). Permodelan Visual Dengan UML. Graha Ilmu, Jakarta.

[11] Suprianto, Dodit. (2008). Buku Pintar Pemrograman PHP. OASE Media, Malang.

[12] Sutanto, Edhy. ( 2004). Sistem Basis Data. . Graha Ilmu, Yogyakarta.

[13] Whitten, Jeffry L., et.al, dkk. (2004). System Analysis and Design Methods. McGraw-Hill, New York. 